\title{
Human papillomavirus genotypes in invasive cervical squamous cell carcinoma in Trinidad
}

\author{
Felicia Hosein, ${ }^{1}$ Wayne Mohammed, ${ }^{1}$ Vanessa Zubach, ${ }^{2}$ \\ George Legall, ${ }^{1}$ and Alberto Severini ${ }^{2}$
}

Suggested citation

Hosein F, Mohammed W, Zubach V, Legall G, Severini A. Human papillomavirus genotypes in invasive cervical squamous cell carcinoma in Trinidad. Rev Panam Salud Publica. 2013;33(4):267-70.

ABSTRACT Objective. To determine the relative contribution of known high-risk human papillomavirus (HPV) genotypes to the occurrence of cervical cancers in Trinidad.

Methods. The distribution of HPV genotypes in cases of invasive cervical squamous cell carcinoma in Trinidad was investigated. This study was a follow-up to an investigation of HPV genotypes in 310 nonsymptomatic women in Trinidad. The latter study showed that cervical HPV prevalence and heterogeneity of genotypes were high in the study population; notably, the genotypes targeted by the available HPV prophylactic vaccines were not the most common types.

Results. The current study of 85 cases of invasive cervical squamous cell carcinomas demonstrated that the previously observed heterogeneity in HPV genotype distribution is lost in cases of invasive cervical cancer, with the vaccine-targeted HPV types HPV 16 and HPV 18 becoming the most prevalent.

Conclusions. HPV 16 and HPV 18 were the primary HPV genotypes associated with cases of invasive squamous cell carcinoma in the current Trinidad study. This strong association leads us to conclude that the HPV vaccines targeting HPV 16 and HPV 18 may contribute to reducing the cervical cancer burden in Trinidad.

Key words Cervix neoplasms prevention; Papillomaviridae; Caribbean region; Trinidad and Tobago.

Cervical cancer is the second most common cancer in women in Trinidad and Tobago, with a high mortality rate among those affected (1). The human papillomavirus (HPV) is the central causal factor in at least $95 \%$ of invasive cervical cancers (2), with at least 25 genotypes of the virus having been linked to

\footnotetext{
1 Para-clinical Sciences, Faculty of Medical Sciences, The University of the West Indies, St. Augustine, Trinidad and Tobago. Send correspondence to: Felicia Hosein, hosein.felicia@gmail.com

2 Viral Sexually Transmitted Diseases Section, National Microbiology Laboratory, Public Health Agency of Canada, Winnipeg, Manitoba, Canada.
}

cancer of the cervix (3). Two prophylactic HPV vaccines are currently available, both of which are effective against highrisk HPV genotypes HPV 16 and HPV 18 (4). These genotypes have been reported to be the most common HPV genotypes found associated with carcinoma in situ and invasive cervical carcinoma $(5,6)$.

A previous study of 310 women from Trinidad, ages 18 to 64 years and with no previous diagnosis of cervical cancer, reported an HPV prevalence of $40.6 \%$, with the majority $(60 \%)$ of infections being high-risk HPV infections. Sixteen high-risk HPV genotypes were identi- fied in that study (7), with HPV 52 and HPV 66 both occurring more frequently than HPV 16 and HPV 18. The five most common high-risk genotypes in that study population were HPV 52, HPV 66, HPV 16, HPV 18, and HPV 58, with relative frequencies of $12.7 \%, 10.3 \%, 9.5 \%$, $8.6 \%$, and $7.9 \%$, respectively (7). Eleven high-risk genotypes-HPV 16, HPV 18, HPV 31, HPV 45, HPV 51, HPV 52, HPV 53, HPV 58, HPV 59, HPV 66, and HPV 82 -were also reported to be associated with cytologic abnormalities in the study population (7). 
Given the observed marked heterogeneity of high-risk HPV genotypes in the latter study, this investigation was undertaken to determine the relative contribution of the known high-risk HPV genotypes to the occurrence of cervical cancers in Trinidad. Such information will serve to establish the usefulness of incorporating HPV vaccination as a public health intervention for reducing the incidence of cervical cancer in this population. Ethical approval for the study was obtained from the Trinidad and Tobago Ministry of Health.

\section{MATERIALS AND METHODS}

A total of 85 formalin-fixed, paraffinembedded tissue specimens of invasive cervical squamous cell carcinoma were obtained from public health institutions in Trinidad and from a local private gynecologic practice. The specimens represented archival material collected over the period 2006 to 2012.

A thin slice of tissue was removed from each tissue block with a disposable scalpel and was used for DNA extraction by treatment with ionic detergents and proteinase K. A 65-base-pair fragment of the HPV L1 gene was amplified using the SPF1/SPF2 consensus primer set according to Kleter et al. (8). It is notable that nested polymerase chain reaction amplification of HPV DNA with the commonly used PGMY (first round) and GP5+/GP6+ (second round) primer sets $(9,10)$ was not successful for these tissue samples, probably because the DNA was degraded as a result of harsh tissue fixing conditions (90\% formalin).

Amplicons from the SPF1/SPF2 polymerase chain reactions were cloned by TOPO $^{\circledR}$ TA cloning (Invitrogen Life Technologies, Grand Island, New York, United States of America) according to the manufacturer's instructions. Both strands of the cloned amplicon were sequenced by automated DNA sequencing using vector primers M13F and M13R at the DNA Core Facility of the National Microbiology Laboratory, Public Health Agency of Canada (Winnipeg, Manitoba). The DNA sequences were aligned against the GenBank database using the BLAST algorithm (National Center for Biotechnology Information, National Library of Medicine, Bethesda, Maryland, United States). HPV genotype assignment was made if $>90 \%$ identity was found.

\section{RESULTS}

HPV DNA was successfully amplified from $78(91.8 \%)$ of the 85 specimens tested. A definite HPV genotype could be determined for 56 (71.8\%) of the HPVpositive specimens (Table 1), with the other $22(28.2 \%)$ recorded as having an indeterminate HPV genotype. The latter represent cases in which the BLAST search proposed more than one equally likely genotype or in which the genotype was determined from a short sequence read ( $<60$ base pairs).

The most common HPV genotypes found were HPV 16 and HPV 18, occurring in $66.1 \%(37 / 56)$ and $17.8 \%(10 / 56)$, respectively, of the 56 cases that could be definitively genotyped. Other HPV genotypes found were HPV 45, which occurred in five cases $(5 / 56,8.9 \%)$, and HPV 33, HPV 35, HPV 39, and HPV 52 , each of which occurred once $(1.8 \%)$ (Table 1).

In this study, HPV 16 and HPV 18 together were associated with $83.9 \%$ of the cases of invasive cervical cancers analyzed. This amount differs significantly from the findings of the previous Trinidad study of women with no previous diagnosis of cervical cancer, in which HPV 16 and HPV 18 together accounted for only $18.2 \%$ of all HPV infections and for $24 \%$ of all high-risk infections (7). Only a subset (7 of 16) of the high-risk HPV genotypes detected in the previous study were found to be associated with the cases of invasive cervical cancer analyzed in this study.

A vast majority of HPV infections are transient, with as much as $90 \%$ of detected infections being cleared within 2 years (11). This fact is particularly true for infections in younger women ( $\leq 25$ years). Progression of cervical $\mathrm{HPV}$ infections to cancer occurs in cases of persistent infections. High-risk HPV genotypes vary in their progressive potential and thus contribute differentially to the development of cervical cancer (12). Given the natural history of cervical HPV infections and the large proportion of younger women in the previous Trinidad study $(46 \%$ were $\leq 30$ years old compared with $7 \% \leq 30$ years old in the current study), it is suggested that the majority of the HPV-positive specimens detected in the previous study represented transient infections, which would not progress to cancer. These infections, however, provided an indication of the heterogeneity in HPV genotypes, including high-risk HPV genotypes that were circulating in the population. All HPV infections detected in the current study represented persistent infections, which had progressed to the stage of invasive cervical carcinoma. The HPV genotypes detected in these specimens, therefore, are likely to represent genotypes with a high progressive potential.

\section{CONCLUSION}

The findings of this study are consistent with other reports $(5,6,13-15)$, which have demonstrated that, in spite of marked heterogeneity in high-risk HPV genotypes among the general population, two high-risk genotypes-HPV 16 and HPV 18-are by far the most frequently associated with cases of invasive cervical cancers. The findings also support suggestions that these two highrisk genotypes have an advantage for persistence and progression to cervical lesions compared with other high-risk HPV genotypes. HPV 45, which was the third most prevalent genotype in this study, has also been reported to have a biological advantage for progression (16) and 6 out of 7 of the HPV genotypes

TABLE 1. Human papillomavirus genotypes and their distribution in 56 formalin-fixed paraffin-embedded tissue specimens of invasive cervical cancer from Trinidad, 2006-2012

\begin{tabular}{lcc}
\hline & \multicolumn{2}{c}{ Frequency } \\
\cline { 2 - 3 } Genotype & Number & Percent \\
\hline HPV 16 & 37 & 66.1 \\
HPV 18 & 10 & 17.8 \\
HPV 45 & 5 & 8.9 \\
HPV 33 & 1 & 1.8 \\
HPV 35 & 1 & 1.8 \\
HPV 39 & 1 & 1.8 \\
HPV 52 & 1 & 1.8 \\
\hline
\end{tabular}


detected in this study are included in the list of $8 \mathrm{HPV}$ genotypes previously reported to account for $95 \%$ of squamous cell carcinomas in pooled data from 11 case-controlled studies (5).

The major limitation to this study was the limited availability of specimens and accompanying demographic data. The specimens used were formalin-fixed, paraffin-embedded tissue samples of invasive cervical squamous cell carcinoma, which were originally prepared for histologic diagnoses and stored as archival patient specimens at two public hospitals and one private gynecologic practice in Trinidad. The original histology slides, from which the original diagnoses were made, were reviewed by the study team's expert pathologist to confirm invasive cervical carcinoma. Apart from date of birth, no other significant demographic data on patients were available.

All specimens that could be located and verified for invasive cervical squamous cell carcinoma for the period 2006 to February 2012 were used in the study.
Because of the poor state of the tissue archives, only 85 useable specimens were obtained. This number is small compared with the total expected number of cases of cervical cancer for the period surveyed. An average of 123 new cases of cervical cancer are expected per year in Trinidad and Tobago (calculated from data on newly reported cases of cervical cancer for the period January 2000 to December 2006, obtained from the National Cancer Registry of Trinidad and Tobago, Wayne Mohammed, personal communication, July 23, 2010). Nevertheless, the number of specimens used in this study is comparable to the number of high-risk HPV infections detected in the previous Trinidad study of nonsymptomatic women (83 of 310), and a comparison of the high-risk HPV genotype profiles of both study populations is, therefore, thought to be valid. As with the previous Trinidad study, the current study population is not representative of the general population. Given the difficulty in obtaining archival tissue samples, an investigation that is representative of

\section{REFERENCES}

1. International Agency for Research on Cancer. GLOBOCAN 2008: cancer incidence, mortality and prevalence worldwide in 2008. Lyon, France: IARC; 2008. Available from: http:// globocan.iarc.fr/factsheet.asp\#WOMEN Accessed 16 May 2012.

2. Bell MC, Schmidt-Grimminger $D$, Patrick $S$, Ryschon T, Linz L, Chauhan SC. High prevalence of human papillomavirus infection in American Indian women of the Northern Plains. Gynecol Oncol. 2007;107(2):236-41.

3. Bouvard V, Baan R, Straif K, Grosse Y, Secretan B, El Ghissassi F, et al. A review of human carcinogens-Part B: biological agents. Lancet Oncol. 2009;10(4):321-2.

4. Stanley M. HPV vaccines: are they the answer? Br Med Bull. 2008;88(1):59-74.

5. Muñoz N, Bosch FX, de Sanjosé S, Herrero R, Castellsagué X, Shah KV, et al. Epidemiologic classification of human papillomavirus types associated with cervical cancer. N Engl J Med. 2003;348:518-27.

6. Clifford GM, Smith JS, Aguado T, Franceschi S. Comparison of HPV type distribution in high-grade cervical lesions and cervical cancer: a meta-analysis. Br J Cancer. 2003;89(1):101-5.

7. Andall-Brereton GM, Hosein F, Salas RA, Mohammed W, Monteil MA, Goleski V, et al. Human papillomavirus genotypes and their prevalence in a cohort of women in Trinidad. Rev Panam Salud Publica. 2011;29(4):220-6.

8. Kleter B, van Doorn LJ, ter Schegget J, Schrauwen L, van Krimpen K, Burger M, et al. Novel short-fragment PCR assay for highly sensitive broad-spectrum detection of anogenital human papillomaviruses. Am J Pathol. 1998;153(6):1731-9.

9. Gravitt PE, Peyton CL, Alessi TQ, Wheeler CM, Coutlée F, Hildesheim A, et al. Improved amplification of genital human papillomaviruses. J Clin Microbiol. 2000;38(1):357-61.

10. Roda Husman AM, Walboomers JM, van den Brule AJ, Meijer CJ, Snijders PJ. The use of general primers GP5 and GP6 elongated at their $3^{\prime}$ ends with adjacent highly conserved sequences improves human papillomavirus detection by PCR. J Gen Virol. 1995;76(4):1057-62.

11. Moscicki AB, Schiffman M, Kjaer S, Villa LL. Chapter 5: updating the natural history of HPV and anogenital cancer. Vaccine. 2006;24:S42-51.

12. Clifford GM, Rana RK, Franceschi S, Smith JS, Gough G, Pimenta JM. Human papillomavirus genotype distribution in low-grade cervical lesions: comparison by geographic region and with cervical cancer. Cancer Epidemiol Biomarkers Prev. 2005;14(5):1157-64. the population would be best conducted through a prospective study.

The combined frequency of association of $83.9 \%$ for HPV 16 and HPV 18 with cases of invasive cervical carcinoma observed in this study is higher than the worldwide average of $70 \%$ to $76 \%$ (11). Therefore, it is concluded that the HPV vaccines targeting HPV 16 and HPV 18 may contribute to reducing the cervical cancer burden in Trinidad.

Acknowledgments. The authors thank the staff of the Eric Williams Medical Sciences Complex and The San Fernando General Hospital for their cooperation during specimen collection. The authors are grateful to consultant gynecologist Anthony Pottinger for contributing specimens for the study.

Funding. The study was funded through a Campus Research and Publication Grant from the University of the West Indies, St. Augustine, Trinidad.

\section{Conflict of interests. None.}

13. Li N, Franceschi S, Howell-Jones R, Snijders PJ, Clifford GM. Human papillomavirus type distribution in 30,848 invasive cervical cancers worldwide: variation by geographical region, histological type and year of publication. Int J Cancer. 2011;128(4):927-35.

14. Naucler P, Da Costa FM, Ljungberg O, Bugalho A, Dillner J. Human papillomavirus genotypes in cervical cancers in Mozambique. J Gen Virol. 2004;85(8):2189-90.

15. Sowjanya AP, Jain M, Poli UR, Padma S, Das M, Shah KV, et al. Prevalence and distribution of high-risk human papillomavirus (HPV) types in invasive squamous cell carcinoma of the cervix and in normal women in Andhra Pradesh, India. BMC Infectious Dis. 2005;5:116.

16. de Sanjosé S, Diaz M, Castellsagué X, Clifford G, Bruni L, Muñoz N, et al. Worldwide prevalence and genotype distribution of cervical human papillomavirus DNA in women with normal cytology: a metaanalysis. Lancet Infect Dis. 2007;7(7):453-9.

Manuscript received on 16 May 2012. Revised version accepted for publication on 26 December 2012. 
RESUMEN Objetivo. Determinar la contribución relativa de los diferentes genotipos de virus de los papilomas humanos (VPH) conocidos como de alto riesgo para la aparición de cáncer cervicouterino en Trinidad.

Genotipos de virus de los Métodos. Se investigó la distribución de los genotipos de VPH en casos de carcipapilomas humanos en carcinoma cervicouterino escamocelular invasor noma cervicouterino escamocelular invasor en Trinidad. Este estudio fue la continuación de una investigación de los genotipos de VPH presentes en 310 mujeres asintomáticas en Trinidad. Este último estudio reveló altas prevalencia de VPH en el cuello uterino y heterogeneidad de los genotipos en la población del estudio; cabe destacar en Trinidad que los genotipos a los que se dirigen las vacunas preventivas de la infección por VPH disponibles no fueron los tipos más frecuentes.

Resultados. El presente estudio, llevado a cabo en 85 casos de carcinoma cervicouterino escamocelular invasor, demostró que la heterogeneidad anteriormente observada en la distribución de genotipos de VPH no se mantiene en los casos de cáncer cervicouterino invasor, y que los tipos de VPH objeto de la vacuna, el VPH 16 y el VPH 18, pasan a ser los más prevalentes.

Conclusiones. En el presente estudio llevado a cabo en Trinidad, el VPH 16 y el VPH 18 fueron los principales genotipos de VPH asociados con los casos de carcinoma escamocelular invasor. Esta estrecha asociación nos lleva a la conclusión de que las vacunas contra el VPH dirigidas contra el VPH 16 y el VPH 18 pueden contribuir a la reducción de la carga de cáncer cervicouterino en Trinidad.

Palabras clave Prevención de cáncer de cuello uterino; Papillomaviridae; región del Caribe; Trinidad y Tobago. 